Article

\title{
Irrigation Management Scale and Water Application Method to Improve Yield and Water Productivity of Field-Grown Strawberries
}

\author{
Guillaume Létourneau *(B) and Jean Caron \\ Department of Soils and Agri-Food Engineering, Laval University, Québec, QC G1V0A6, Canada; \\ jean.caron@fsaa.ulaval.ca \\ * Correspondence: guillaume.letourneau.1@ulaval.ca; Tel.: +1-418-656-2131 (ext. 406642); Fax.: +1-418-656-3723
}

Received: 17 April 2019; Accepted: 29 May 2019; Published: 1 June 2019

\begin{abstract}
Improvements in water productivity are of primary importance for maintaining agricultural productivity and sustainability. Water potential-based irrigation management has proven effective for this purpose with many different crops, including strawberries. However, problems related to spatial variability of soil properties and irrigation efficiency were reported when applying this management method to strawberries in soils with rock fragments. In this study, a field-scale experiment was performed to evaluate the impacts of three irrigation management scales and a pulsed water application method on strawberry yield and water productivity. An analytical solution to Richards' equation was also used to establish critical soil water potentials for this crop and evaluate the effects of the variability in the soil properties. Results showed that spatial variability of soil properties at the experimental site was important but not enough to influence crop response to irrigation practices. The studied properties did not present any spatial structure that could allow establishing specific management zones. A four-fold reduction in the size of the irrigation management zones had no effect on yield and increased the water applications. Pulsed application led to significant yield $(22 \%)$ and water productivity $(36 \%)$ increases compared with the standard water application method used by the producer at the experimental site.
\end{abstract}

Keywords: soil water potential-based irrigation; pulsed irrigation; irrigation management scale; strawberry irrigation

\section{Introduction}

In the face of a growing world population and a decreasing availability of fresh water, it is crucial to rationalize agricultural water use [1]. Crop irrigation is estimated to account for $45 \%$ of freshwater uptake within the OECD countries, with values as high as 90\% for individual countries [2]. Hence, any improvement in irrigation efficiency could greatly benefit the global balance of freshwater.

Strawberries (Fragaria $\times$ ananassa Duch.) are generally considered to have high water requirements [3]. In North American commercial field productions, day-neutral strawberries are generally grown in raised beds covered with polyethylene mulch and irrigated with a subsurface drip irrigation (SDI) system [4]. This system has a potential water application efficiency of $85 \%$ to $90 \%$. However, the efficiency can be limited by the effects of: (1) Spatio-temporal variability in soil properties and plant water requirements [5-8], (2) moisture distribution patterns of the irrigation system [9], and (3) the use of inadequate irrigation management criteria [10].

The measurement of the soil water potential (SWP) with tensiometers has proven to be an effective irrigation initiation criterion that improves crop yield and water productivity (WP) for different crops under a wide range of soils, climatic conditions, and agricultural practices [11]. Studies have shown 
that marketable yield and WP can benefit from SWP-based irrigation management of cranberry in sprinkler-irrigated sandy soils [12,13], romaine lettuce, onion and celery in muck soils $[14,15]$, and SDI-irrigated strawberries in various soils under field [10,16-18] or tunnel [19] conditions. However, although the impacts of SWP-based irrigation management on strawberry yield have been demonstrated on different sites, the study from Létourneau et al. [10] also reported limited influence for soils with a significant proportion of shale fragments (particle size $>2 \mathrm{~mm}$ ). The same study suggested that this was due to spatial variability in soil hydraulic properties, most likely influenced by the proportion of shale fragments and/or the inadequacy of the moisture distribution pattern (lack of lateral distribution, significant leaching) from the SDI irrigation system.

The use of remote sensing or high-density electrical conductivity mapping combined with geostatistical or deterministic spatial analysis to assess the spatial variability of soil properties is well documented. These approaches have been widely applied, primarily in cereal production, for variable-rate fertilization and pest/weed/disease control. Fewer studies have focused on delineating the management zones to which a specific irrigation scheduling could be applied. Some studies have reported increases in actual or simulated yield using local irrigation management that accounts for the variability in soil properties $[20,21]$. The literature shows conflicting results regarding water application and WP, with some studies reporting water savings [22,23] and others reporting increases in applied irrigation volume [14,24]. Périard et al. [14] suggested that this might be due to differences in scale among the experiments or simulations. Most of these studies were conducted using central pivot or sprinkler irrigation systems for crops requiring low frequency irrigation [22,25]. Very little information on the effects of irrigation scale management with SDI systems for field strawberry production is presently available.

Many studies have focused on design parameters for SDI systems, such as the number of laterals per bed, emitter depth, application rate and spacing, as well as management parameters, such as irrigation frequency and duration [9,26-30]. The determination of optimal SDI system parameters adapted to field conditions can be facilitated by empirical, semi-empirical, or analytical models [28,31]. Most analytical models (Philip, 1984, 1968; Warrick, 1974; Wooding, 1968) are based on a solution of Richards' transport equation with specific assumptions and boundary conditions, and they do not account for root water uptake. Still, many analytical models were reported to predict wetting patterns that were in good agreement with field observations [32]. Solutions for water flow and the distribution of pressure head that account for water flow, surface fluxes and root water uptake were derived by Yuan and $\mathrm{Lu}$ [33]. These solutions are not specific to SDI irrigation but still have proven efficient in the determination of critical soil water potentials for sprinkler-irrigated celery and onions [15] and strawberry [34]. Other solutions specific to SDI irrigation were derived and implemented into the DIDAS software by Friedman et al. [35].

Numerical simulations have shown that in different soils, the horizontal water movement could be slightly increased with low discharge rates and pulsed irrigations [30]. The irrigation frequency and the emitter discharge rate were also found to affect nitrate leaching beneath the root zone [36]. Increasing irrigation frequency was also found to influence root distribution with depth $[37,38]$ and root water uptake [1]. Most of these studies are theoretical, and their applicability to field conditions still requires validation. In field experiments, high irrigation frequency led to an equivalent or improved yield and increased WP in bell peppers [39] and sunflowers [38] compared with standard practices. However, there is presently not much information available with respect to the possible interaction between site-specific management and the water application methods of SDI-irrigated crops with a high-water demand, such as strawberries.

The objective of this study was to evaluate the impacts of: (1) Irrigation management scale and (2) irrigation frequency on day-neutral strawberry yield and water productivity in a field with a significant fraction of shale fragments. 


\section{Materials and Methods}

An experiment was conducted on a commercial site located near Québec City, QC, CAN $\left(46^{\circ} 54^{\prime} \mathrm{N}\right.$, $70^{\circ} 56^{\prime} \mathrm{W}, 29 \mathrm{~m}$ AMSL), during the 2012 growing season. According to the Canadian Soil Classification System [40], soils in the area are silt loams to silty clay loams from the Orléans series. The field had a constant $4 \%$ slope in the north-south direction and was divided into three sections of equal width in the east-west direction by natural wind barriers. Bare root day-neutral strawberry plants (cv. seascape) were planted on 20 May 2012 in raised beds $140 \mathrm{~cm}$ apart (center to center) with two plant rows per bed for a density of 54,800 plants per hectare. The beds were $90 \mathrm{~cm}$ wide, $30 \mathrm{~cm}$ high, and covered with black polyethylene mulch. The area of the experimental site was $2.67 \mathrm{ha}$, and the area of the individual plots ranged between 0.11 and 0.45 ha. Except for irrigation management, all agricultural operations (fertilization, pest and disease control, pruning of flowers and runners, and general maintenance) were conducted in a similar manner on all plots per the commercial producer standard procedures.

The experimental area was divided into 12 irrigation zones of equal width (nine beds or $12 \mathrm{~m}$ ) but whose length varied between 180 and $90 \mathrm{~m}$ (Figure 1A). In all zones, irrigation water was delivered by a single drip lateral per bed $\left(1.6 \mathrm{~cm}\right.$ diameter, $20 \mathrm{~cm}$ emitter spacing, and $0.5 \mathrm{~L} \mathrm{~h}^{-1}$ flow rate (Aquatraxx PBX, Toro-Irrigation, Bloomington, MN, USA)), buried 3-4 cm under the soil surface at the apex of the bed. For each individual zone, all the drip laterals were connected to a single tertiary water pipe. Upstream from the drip laterals, the water flow in each tertiary pipe was controlled by a manual gate valve (model IV 0818-10, Dubois Agrinovation, St-Rémi, QC, Canada), and the pressure head was adjusted to $62 \mathrm{kPa}$ by a pressure-regulating valve (model PRV.75-112, Dubois Agrinovation, St-Rémi, QC, Canada). A water totalizer (model LR-F-208, Les Compteurs Lecompte ltd, Ste-Hyacinthe, QC, Canada) was also installed on the tertiary pipe upstream from the pressure-regulating valves (Figure 1B). This setup allowed to individually control and measure the water flow to each individual zone while maintaining the pressure head in the drip laterals within the acceptable operating range for the drip emitters. Due to elevation differences within the zones, the pressure head in the drip laterals was expected to vary considerably, especially for longer zones. However, pressure variations as a function of the drip lateral length were calculated with the Hazen-Williams equation [41]. It showed that while the pressure gain was more important for longer zones, it did not significantly increase the variability of the emitter flow rate. As shown in Figure A1, the average and the coefficient of variation of emitter flow rate and the total flow rate per unit drip lateral length did not vary significantly for the two zone lengths considered in this study. For the remainder of this paper, a zone will be defined as a part of the field in which the water pressure and water flow can be controlled independently (as previously described), while a plot (discussed further in the following section) will be defined as a part of the field to which a specific irrigation management treatment was applied.

Four treatments were applied in a complete randomized block design with 3 replications. The blocks consisted of field sections separated with natural wind barriers. To evaluate the effect of irrigation management scale on yield and WP, the first three experimental treatments differed only by the size of the plot managed based on SWP measurements from a single monitoring station. The first treatment (Global) reproduced a large-scale management typically practiced by producers in the area where the experiment took place. For this treatment, a plot was $360 \mathrm{~m}$ long (two $180 \mathrm{~m}$ zones). The second treatment (Inter) aimed to reproduce an intermediate management. For this treatment, a plot consisted of a $180 \mathrm{~m}$ long irrigation zone. The third treatment (Local) reproduced a small-scale management. For this treatment, a plot consisted of a $90 \mathrm{~m}$ long zone. A fourth treatment (Pulse) was applied to evaluate the effect of water application method on yield and WP at the smallest management scale. For this treatment, a plot also consisted of a $90 \mathrm{~m}$ long zone. 


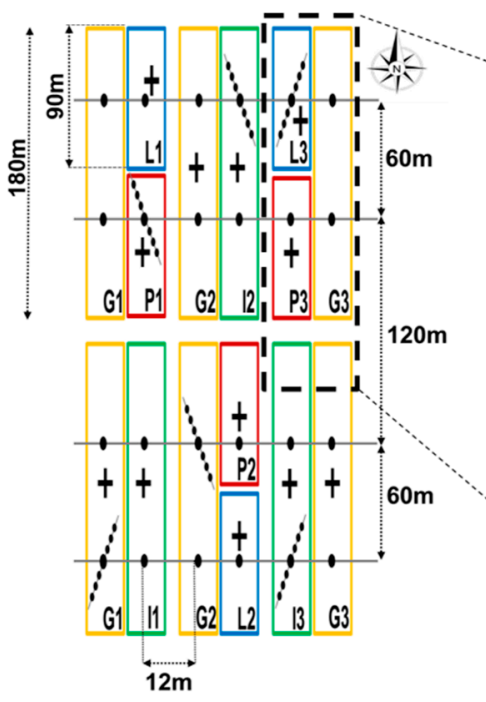

A

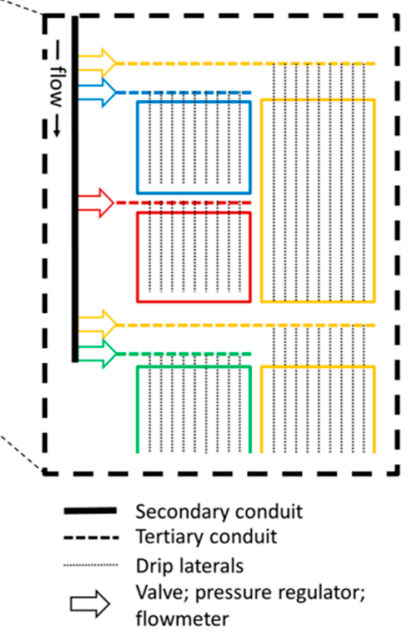

B

Figure 1. (A) Position of the irrigation zones (rectangles), soil sampling sites (dots), monitoring stations (crosses), soil sampling main transects (horizontal lines), and soil sampling sub-transects (diagonal lines) in the field (The letter and the number in the annotations in the lower-right corner of each zone represent the first letter of the treatment (Global, Local, Inter, or Pulse) and the replicate, respectively. (B) Zoom of the irrigation system setup.

The irrigation management of each plot was based on SWP measurements. A monitoring station consisting of two buried wireless tensiometers (Hortau, QC, CAN) was installed in 12 of 15 zones (Figure 1A). SWP was measured and transmitted online at five-minute intervals. A shallow probe, used to initiate irrigation, was installed at a depth of $15 \mathrm{~cm}$ at the outer limit of the wetting bulb from a drip emitter, i.e., a horizontal distance of 5 to $10 \mathrm{~cm}$ from the emitter. An additional probe was installed at a depth of $30 \mathrm{~cm}$ directly under the emitter and was used to adjust the irrigation duration to avoid leaching under the root zone. For all treatments, irrigation was initiated when a predefined irrigation threshold of $-18 \mathrm{kPa}$ was reached at a depth of $15 \mathrm{~cm}$. This threshold was selected based on the results of previous studies at nearby sites $[10,16]$. Detailed information about the irrigation initiation and adjustment of irrigation duration is provided in Létourneau et al. [10]. For Global, Inter and Local, water was applied when the threshold was reached through a single irrigation event lasting between 40 and 60 min depending on crop development. For Pulse, water application was divided into 2 events separated by 2 to $3 \mathrm{~h}$. Each event lasted for half of the irrigation time applied to the other treatments. For Global, all three replicates were simultaneously irrigated when the average SWP from all three replicates reached the threshold. This reproduced standard management of a large field based on average measurements from randomly positioned monitoring stations. For all other treatments, each replicate was individually monitored and irrigated to reproduce site-specific management. The experimental setup is summarized in Figure 2. Henceforth, Global, Inter and Local will be referred to as the management scale treatments.

The management scale treatments were established in this manner because when the experiment was set up, in early May 2012, a detailed analysis of the spatial variability of soil properties was not yet available. However, soil survey maps of the area and preliminary experiments on nearby sites had shown that a gradient in arable soil depth, soil texture, or in the proportion of rock fragments would most likely be in the north-south direction. Additionally, to maximize the cultivated surface within the field, to facilitate agricultural operations, and to protect against dominant winds, the beds were almost exclusively oriented in the north-south direction in the area surrounding the experimental site. Hence, the most practical way to reduce the irrigation management scale in this field was to reduce the length of the irrigation management zones in the north-south direction. 


\begin{tabular}{|c|c|c|c|c|}
\hline Treatment & Global & Inter & Local & Pulse \\
\hline \multirow{2}{*}{ Effects evaluated } & \multicolumn{3}{|c|}{ Management scale } & \\
\hline & & & \multicolumn{2}{|c|}{ Water application } \\
\hline $\begin{array}{l}\text { Experimental plot } \\
\text { length }\end{array}$ & $\begin{array}{l}\text { Two } 180 \mathrm{~m} \\
\text { long zones }\end{array}$ & $\begin{array}{l}\text { One } 180 \mathrm{~m} \\
\text { long zone }\end{array}$ & $\begin{array}{l}\text { One } 90 \mathrm{~m} \\
\text { long zone }\end{array}$ & $\begin{array}{l}\text { One } 90 \mathrm{~m} \\
\text { long zone }\end{array}$ \\
\hline Water application & \multicolumn{3}{|c|}{$40-60 \mathrm{~min}$; one event } & $\begin{array}{l}20-30 \text { min; } \\
\text { two events }\end{array}$ \\
\hline Irrigation initiation & $\begin{array}{c}\text { All replicates } \\
\text { irrigated } \\
\text { simultaneously } \\
\text { (standard } \\
\text { management) }\end{array}$ & \multicolumn{3}{|c|}{$\begin{array}{c}\text { Each replicate irrigated individually } \\
\text { (site-specific management) }\end{array}$} \\
\hline
\end{tabular}

Figure 2. Schematic summary of the experimental setup.

Two to three times a week, depending on weather conditions and crop development, the marketable yield was harvested from six full-length beds per plot. Weekly, two samples of 50-100 fruits were randomly collected from each plot. These fruits were counted and weighed to calculate the average fruit size. Within these samples, two fruits of equal size and color were selected for a firmness measurement with a penetrometer (FT-2, QA supplies, Norfolk, VA, USA) and sugar content measurement (brix index) with a refractometer (PAL-1, ATAGO CO, Tokyo, Japan). The volume of applied irrigation water was obtained from weekly surveys of flow totalizers installed on the supply pipe of every plot. Early in the season, three healthy plants of average size were selected and marked at two randomly placed sampling sites per plot. From early June to mid-July, these plants were used for a weekly measurement of leaf coverage (the longest leaf-covered distance in two perpendicular directions) and crown diameter. These measurements were halted when leaves from adjacent plants began to intertwine. The linear part of the growth curves was then used to calculate the leaf coverage and crown diameter growth rates by linear regression.

Soil samples were collected from the beds between 25 May and 1 June 2012. Georeferenced samples were collected from four main transects in the east-west direction (Figure 1A). Each main transect consisted of six sampling locations approximately $12 \mathrm{~m}$ apart (9 beds). Six additional northwest-southeast or northeast-southwest diagonal sub-transects, each consisting of six sampling locations $2.5 \mathrm{~m}$ apart, were positioned to cover most of the field (Figure 1A), for a total of 60 sampling locations.

The soil texture was measured at every other point along the main transects at a depth of $15 \mathrm{~cm}$ and at every third point at a depth of $30 \mathrm{~cm}$ following the standard hydrometer method [42]. Soil cores ( $54 \mathrm{~mm}$ high, $83 \mathrm{~mm}$ i.d.) were collected at all points ( $15 \mathrm{~cm}$ depth) and every third point ( $30 \mathrm{~cm}$ depth) from the main transects to measure the bulk density $\left(\rho_{\text {bulk }}\right)$ and the saturated hydraulic conductivity (Ks-core) using the constant head method [43]. Thirteen of the cores collected at a $15 \mathrm{~cm}$ depth were randomly selected to obtain the water retention curves with pressure cells [44], and the unsaturated hydraulic conductivity with the multistep outflow method [45]. The easily available water (EAW) was calculated from the water retention curves as the difference between the water content at bed capacity $(-2.5 \mathrm{kPa})$ and the water content at the irrigation initiation threshold $(-18 \mathrm{kPa})$. The SWP at bed capacity is the average SWP 2 to 3 hours after an irrigation event. Details about this concept are given in Létourneau et al. [10]. The in situ hydraulic conductivity (Ks-in situ) was also measured at all sampling points with a constant head infiltrometer [46]. The proportion of rock fragments, i.e., particles with a diameter greater than $2 \mathrm{~mm}$ in the 0-30 cm horizon, was measured from samples collected at all points on the main transects using the procedure described by Grossman and Reinsch [47]. 
The SWP at which root water uptake should become limiting for root uptake was calculated from the 13 unsaturated hydraulic conductivity curves at a depth of $15 \mathrm{~cm}$, following the approach presented in Rekika et al. [15]. As a first step, the parameters from the Gardner (1958) hydraulic model,

$$
K(h)=K_{s G} e^{\alpha^{*} h}
$$

where $K$ (LT-1) is the unsaturated hydraulic conductivity, $K_{s} G(\mathrm{LT}-1)$ is the fitted saturated hydraulic conductivity, $h(\mathrm{~L})$ is the SWP, and $\alpha^{*}(\mathrm{~L}-1)$ is a fitted shape parameter, were obtained by inverse modelling of the experimental data with the minpack.lm package in R [48]. The optimized parameters were then used as inputs in the equations proposed by Rekika et al. [15], which were obtained by adapting an analytical solution of a steady-state form of Richards' equation considering evaporation, root water uptake, and SWP distribution with depth [33] to the determination of the critical SWP for root uptake $\left(\mathrm{h}_{\mathrm{c}}\right)$,

$$
\begin{gathered}
h_{1}=\frac{1}{\alpha^{*}} \ln \left(-\frac{1}{\alpha^{*} K_{s G}}\left(q_{0} \alpha^{*} e^{-\alpha^{*} L}-q_{0} \alpha^{*}+S_{0} e^{-\alpha^{*} L} \alpha^{*} L+S_{0} e^{-\alpha^{*} L}-S_{0}\right)\right)+L \\
h_{\mathrm{c}}=\frac{1}{\alpha^{*}}\left(\ln \left\{\frac{1}{\alpha^{*} K_{s G}}\left[\begin{array}{c}
K_{s G} e^{-\alpha^{*}\left(-h_{1}+z_{o b s}\right)} \alpha^{*}+q_{0} \alpha^{*} e^{-\alpha^{*} z_{o b s}}-q_{0} \alpha^{*}+S_{0} e^{-\alpha^{*} z_{o b s}} \alpha^{*} L+ \\
S_{0} e^{-\alpha^{*} z_{o b s}}-S_{0} \alpha^{*} L+S_{0} \alpha^{*} z_{o b s}-S_{0}
\end{array}\right]\right\}\right)
\end{gathered}
$$

where $h_{1}$ is the asymptotic soil pressure head to maintain throughout all the domain $(\mathrm{cm}), L$ is the depth of the root zone $(\mathrm{cm}), z_{o b s}$ is the depth for which $h_{c}$ is calculated, $S 0$ is the root water uptake rate $\left(\mathrm{cm} \mathrm{h}^{-1}\right)$ and $q_{0}$ is the steady-state soil surface evaporation $\left(\mathrm{cm} \mathrm{h}^{-1}\right)$. The model parameters were selected to represent conditions observed in the field. Hence, $\mathrm{L}$ was set to $30 \mathrm{~cm}, z_{\mathrm{obs}}$ was set to $15 \mathrm{~cm}$, $S_{0}$ was set to $8.33 \times 10^{-3} \mathrm{~cm} \mathrm{~h}^{-1}$ (transpirative demand of $4 \mathrm{~mm}$ over a period of 12 hours with a crop coefficient of 0.75 and a rooting depth of $30 \mathrm{~cm}$ ), and $\mathrm{q}_{0}$ was set to $1.38 \times 10^{-4} \mathrm{~cm} \mathrm{~h}^{-1}$ (evaporation rate of $0.5 \mathrm{~mm}$ per day). The same approach was also used to calculate $h_{c}$ for theoretical soils from 12 major classes. Twelve theoretical unsaturated hydraulic conductivity curves (Figure 3) were obtained by direct calculations with the class-averaged parameters of the van Genuchten (1980) hydraulic model, as predicted by the ROSETTA model [49]. Then, the Gardner model parameters were obtained by inverse modelling with the theoretical curves for $h_{c}$ calculations.

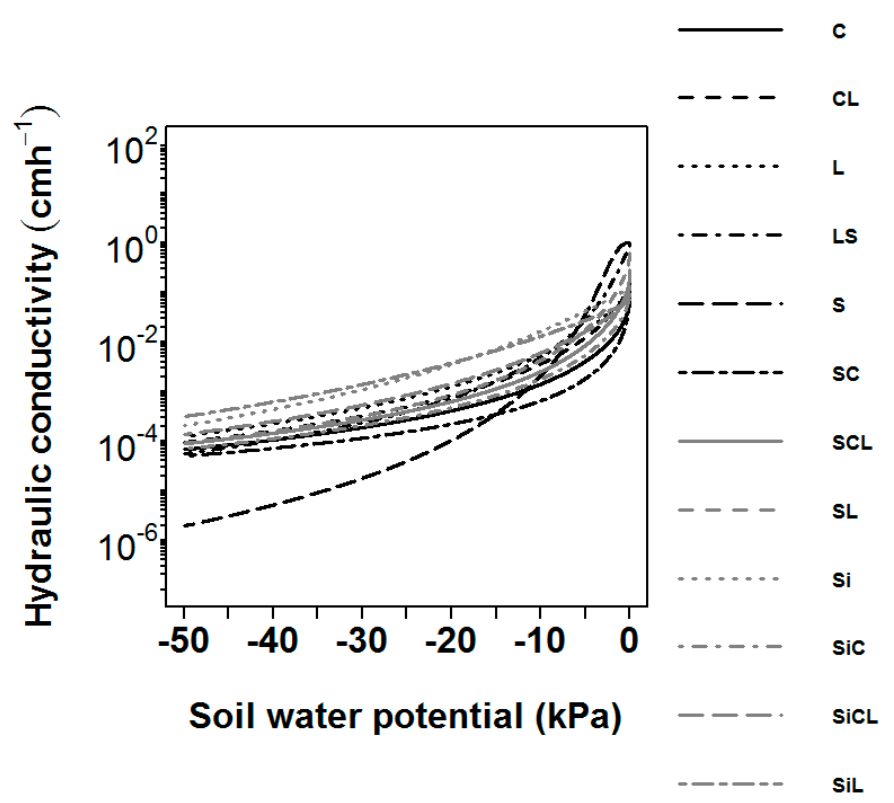

Figure 3. Theoretical unsaturated hydraulic conductivity curves generated by direct calculation of the class average van Genuchten (1980) hydraulic model parameters predicted by the ROSETTA model. (Abbreviations used for soil classes are: $\mathrm{S}=$ sand, $\mathrm{Si}=$ silt, $\mathrm{C}=$ clay, and $\mathrm{L}=$ loam) 
Statistical analysis of the marketable yield results was performed by using a linear mixed-effects repeated measures model with the nlme package in R [50]. For water use, fruit quality, and growth indicator measurements, a standard generalized linear model ANOVA and least significant difference (LSD) multiple comparison tests were conducted using R [51]. For soil properties (when enough data points were available), after verification that anisotropy did not have any effect on the spatial structure of the variance [52], an omni-directional experimental variogram $(\gamma(\mathrm{h}))$ was computed using

$$
\gamma(h)=\frac{1}{2 N(h)} \sum_{i=1}^{N(h)}\left[Z\left(x_{i}\right)-Z\left(x_{i}+h\right)\right]^{2}
$$

where $\gamma(h)$ is the semi-variance, $x_{i}$ is the sampling location, $h$ (meters) is the lag distance between observation pairs, $N$ is the number of observation pairs and $Z$ is the value of the soil property. Standard variogram models were fitted to the experimental data with a restricted maximum likelihood approach using the geoR package in R [53], and the best fit model was chosen based on the Akaike information criterion (AIC). When the semi-variogram showed a significant structure, the spatial variability of the soil properties was interpolated and mapped by ordinary kriging.

\section{Results}

\subsection{Soil Properties}

As shown in Table 1, the soil texture at the experimental site, particularly the sand content, showed significant variability at both measurement depths. A substantial (up to $35 \%$ ) and variable (coefficient of variation $=85 \%$ ) fraction of rock fragments $2 \mathrm{~mm}$ was observed in the $0-30 \mathrm{~cm}$ horizon, which is consistent with the description of the Orléans series.

Table 1. Soil texture at the depths of 15 and $30 \mathrm{~cm}$ and the proportion of rock fragments in the 0-30 cm horizon.

\begin{tabular}{cccccccc}
\hline & \multicolumn{3}{c}{$\mathbf{1 5} \mathbf{c m}$ Depth } & \multicolumn{3}{c}{$\mathbf{3 0} \mathbf{c m}$ Depth } & \multicolumn{2}{c}{ 0-30 cm Depth } \\
& Clay & Silt & Sand & Clay & Silt & Sand & Rock Fragments \\
\hline & $\mathbf{( \% )}$ & $\mathbf{( \% )}$ & $\mathbf{( \% )}$ & $\mathbf{( \% )}$ & $\mathbf{( \% )}$ & $\mathbf{( \% )}$ & $\mathbf{( \% )}$ \\
\hline average & 12.7 & 59.6 & 27.7 & 12.5 & 57.2 & 30.3 & 12.1 \\
max & 16.7 & 72.4 & 51.3 & 16.4 & 65.0 & 41.8 & 34.8 \\
min & 8.5 & 39.9 & 11.3 & 7.7 & 47.2 & 20.9 & 1.6 \\
standard deviation & 2.6 & 11.0 & 13.4 & 2.8 & 5.3 & 7.0 & 10.3 \\
coefficient of variation (\%) & 20.6 & 18.4 & 48.2 & 22.2 & 9.2 & 23.0 & 85.3 \\
number of samples & 13 & 13 & 13 & 7 & 7 & 7 & 24 \\
\hline
\end{tabular}

An average of $82.7 \%$ of the rock fragments were within the $2.0-9.5 \mathrm{~mm}$ range, with most of the remaining fraction smaller than $25.2 \mathrm{~mm}$. As shown in Figure 4, there was an important gradient in the proportion of rock fragments in the north-south direction. It must be noted that the interpolation of the rock fragment proportion over the experimental area presented in Figure 4 was not based on a good fit of the variogram model to the experimental variogram. Hence, the interpolation standard error is important, and Figure 4 only provides a rough visual description of the variability of this property. Still, this is consistent with studies reporting that the variability of the rock fragment fraction is greater along than across the slope of a rock formation $[54,55]$. This also confirms that reducing the length of the experimental plots in the north-south direction was a proper way to evaluate the impacts of various management scales.

Such variability in the rock fragment proportion was expected to affect hydraulic conductivity $[54,56,57]$. As shown in Table 2 , the saturated hydraulic conductivities, whether measured in situ or by laboratory measurements on soil cores at two depths, were very high and varied as much as $200 \mathrm{~cm} \mathrm{~h}^{-1}$ between sampling sites. At a $15 \mathrm{~cm}$ depth, the coefficient of variation for hydraulic 
conductivity was similar to that of the rock fragment proportion (Table 1), and it was much higher at $30 \mathrm{~cm}$ depth. Such variability in saturated hydraulic conductivity could considerably influence the leaching of water and fertilizers under the root zone following irrigation events.

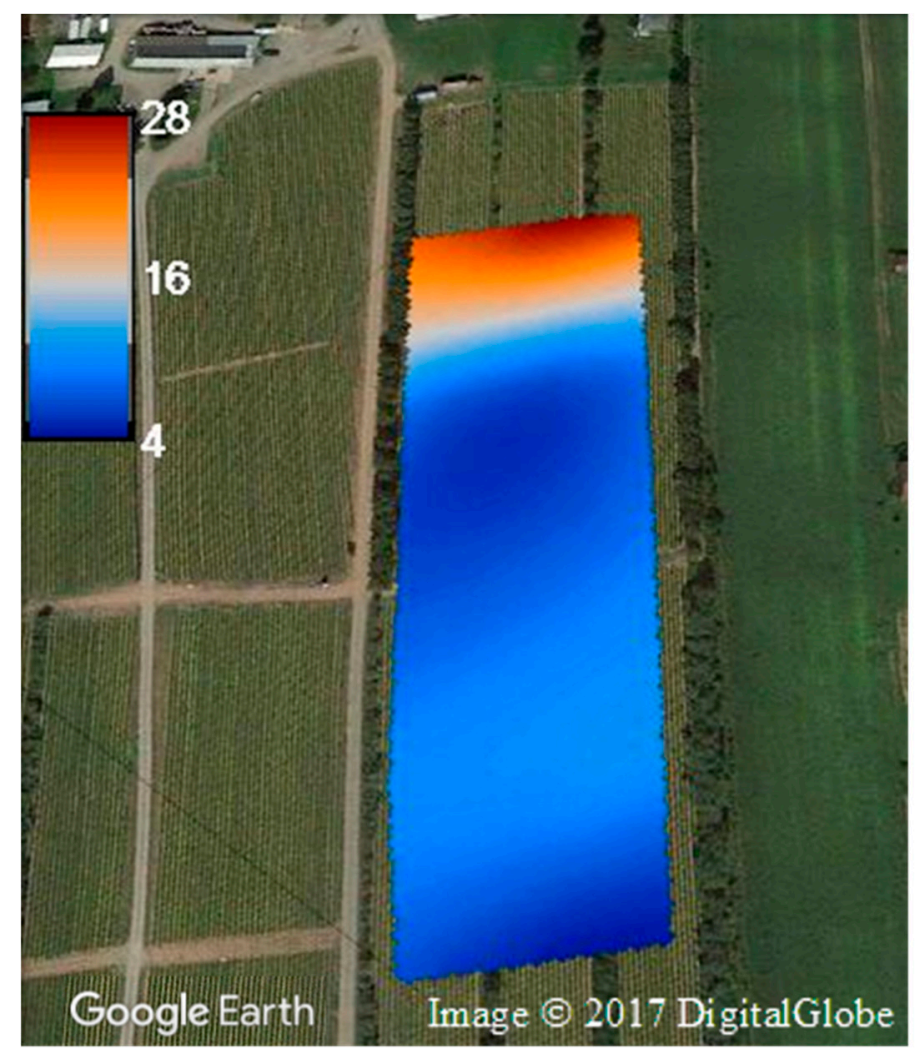

Figure 4. Spatial distribution of the fraction of soil particles (\%) with a diameter $>2 \mathrm{~mm}$ in the experimental field.

Table 2. Physical properties of the soil of the experimental site. $\rho_{\text {bulk }}$ is the soil bulk density, EAW is the easily available water, $\mathrm{K}_{\mathrm{s}}$-core and $\mathrm{Ks}$-in situ are saturated hydraulic conductivities measured from core sample or in situ, respectively.

\begin{tabular}{|c|c|c|c|c|c|c|c|}
\hline & \multicolumn{4}{|c|}{$15 \mathrm{~cm}$ Depth } & \multicolumn{3}{|c|}{$30 \mathrm{~cm}$ Depth } \\
\hline & $\rho_{\text {bulk }}$ & $\mathrm{K}_{\mathrm{S}}$-Core & $\mathrm{K}_{\mathrm{S}}$-in Situ & EAW & $\rho_{\text {bulk }}$ & $\mathrm{K}_{\mathrm{S}}$-Core & $\mathrm{K}_{\mathrm{S}}$-in Situ \\
\hline & $\left(\mathrm{g} \mathrm{cm}^{-3}\right)$ & $\left(\mathrm{cm} \mathrm{h}^{-1}\right)$ & $\left(\mathrm{cm} \mathrm{h}^{-1}\right)$ & $\left(\mathrm{g} \mathrm{cm}^{-3}\right)$ & $\left(\mathrm{g} \mathrm{cm}^{-3}\right)$ & $\left(\mathrm{cm} \mathrm{h}^{-1}\right)$ & $\left(\mathrm{cm} \mathrm{h}^{-1}\right)$ \\
\hline average & 1.24 & 100.2 & 47.1 & 0.05 & 1.62 & 51.6 & 8.5 \\
\hline $\max$ & 1.49 & 197.8 & 220.7 & 0.07 & 1.71 & 278.6 & 28.4 \\
\hline $\min$ & 1.06 & 3.0 & 0.0 & 0.02 & 1.47 & 0.3 & 0.0 \\
\hline standard deviation & 0.10 & 59.9 & 34.4 & 0.01 & 0.08 & 87.0 & 10.2 \\
\hline $\begin{array}{l}\text { coefficient of } \\
\text { variation }(\%)\end{array}$ & 8.38 & 59.8 & 73.0 & 25.0 & 5.00 & 168.6 & 119.7 \\
\hline number of samples & 61 & 10 & 49.0 & 13 & 9 & 8 & 10.0 \\
\hline
\end{tabular}

Significant variability was also observed in soil water retention and unsaturated hydraulic conductivity (Figure 5). The variability in the water retention curves mostly affected the saturated and residual water contents, which varied by as much as $20 \%$ and $10 \%$, respectively. However, all the individual curves presented a similar shape (Figure 5A). A very sharp decrease in water content was observed between soil saturation and a SWP around $-10 \mathrm{kPa}$, at which point the curves almost become flat, and the water content slowly decreases with decreasing SWP. Despite the variability in water retention curves, EAW was similar between the sampling sites, with an average value of $0.05 \mathrm{~cm}^{3} \mathrm{~cm}^{-3}$ (Table 2). In all cases, water availability could rapidly become a limiting factor at SWP 
lower than -10 to $-15 \mathrm{kPa}$, as from this point great differences in SWP are required to induce small changes in water content.
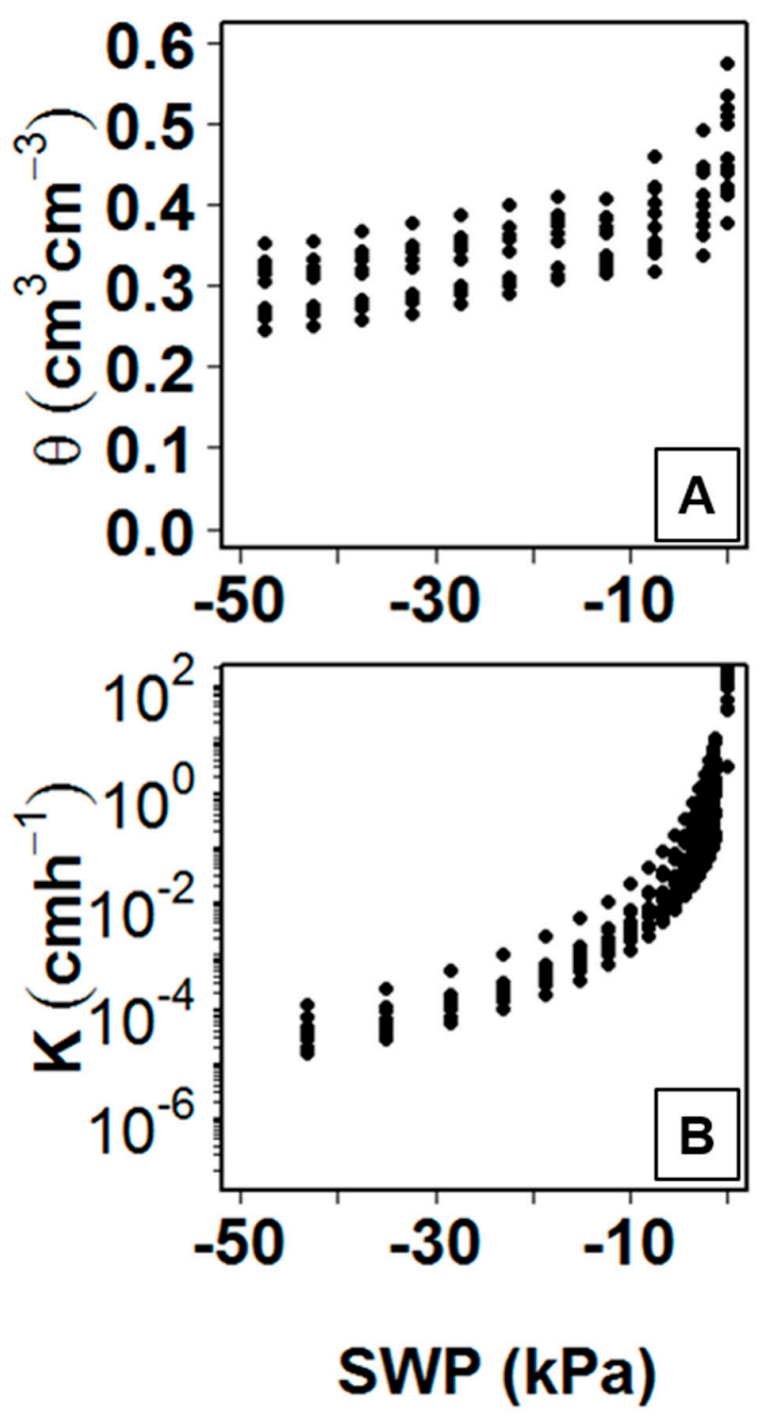

Figure 5. Extent of the observed variability in (A) water retention and (B) hydraulic conductivity as a function of soil matric potential (SWP) on the experimental site.

The unsaturated hydraulic conductivity curves (Figure 5B) exhibited a similar bi-modal pattern. The shape of the curves is similar to what would be expected for a coarse sand, which suggests that soil texture alone is not a good indicator of the soil hydraulic behavior in the presence of rock fragments. The shape of the water content and hydraulic conductivity curves suggests that gravitational and preferential water flows have a major influence on soil hydrodynamics at this site. Gravitational flows generally take place in macro-pores, whose proportions are affected by the particle size distribution and orientation of soil and rock particles.

The soil bulk density (Table 2) was also variable but to a lesser extent than the other measured properties. This is most likely because $\rho_{\text {bulk }}$ measurement is a simple procedure less prone to experimental error than water retention or hydraulic conductivity properties. However, in these specific conditions, $\rho_{\text {bulk }}$ is most likely influenced by the proportion and orientation of schist fragments with a diameter $>2 \mathrm{~mm}$, which in turn could influence water availability and movement through the soil matrix [54,58-60]. 


\subsection{Spatial Variability of Soil Properties}

For all soil properties measured on this site $\left(\rho_{\text {bulk }}, \mathrm{Ks}\right.$-core, $\mathrm{K}_{\mathrm{s}}$-in situ, EAW, particle size distribution, rock fragments proportion), the geostatistical analysis showed no spatial structure (not shown). The experimental semi-variograms mainly exhibited an important nugget effect and no range, meaning that the spatial variability of the soil properties was of a random nature at the measurement scale used in this experiment. This could be explained by the fact that tillage and cultural bed preparation practices have an important influence on the extent of the within-bed variability of these properties $[54,59,61]$. Because these operations are typically repeated every season, a random temporal variability component is added, making it unrealistic and impractical to establish irrigation management zones based on soil properties mapping for this site. This result differs from previous studies on the use of geostatistics for precision irrigation purposes $[5,7,62]$.

\subsection{Root Uptake Limiting SWP}

The root uptake limiting SWP $\left(\mathrm{h}_{\mathrm{c}}\right)$ calculated with the Rekika et al. [15] equations from the unsaturated hydraulic conductivity curves obtained from measurements at the experimental site and for the theoretical class averaged soils are presented in Table 3 . The $h_{c}$ values from the unsaturated conductivities measured at the experimental site varied between -8 and $-17.9 \mathrm{kPa}$ with an average of $-12.1 \pm 2.4 \mathrm{kPa}$. This is consistent with critical SWP between -8 and $-12 \mathrm{kPa}$ previously reported for strawberries [10]. The variographic analysis for hc showed no consistent spatial structure and no spatial correlation between hc and the proportion of rock fragments or any other measured property could be found. Still the average $h_{c}$ values strongly contrasted from what would be expected for a theoretical silty clay loam $(-23.2 \mathrm{kPa})$ and resembled more the $\mathrm{h}_{\mathrm{c}}$ value expected for a theoretical clay or a silty clay (Table 3). This suggests that, as expected, the rock fragment proportion strongly modifies the hydraulic behavior of the soil, but that its influence is randomly distributed throughout the experimental field, most likely due to the random effects of tillage and bed preparation.

Table 3. Fitted Gardner (1958) hydraulic model parameters and calculated root uptake limiting SWP calculated from the observed properties and the theoretical soils $\left(\mathrm{K}_{\mathrm{sG}}\right.$ and $\alpha^{*}$ are the fitted Gardner (1958) model parameters for soil classes: $\mathrm{S}=$ sand, $\mathrm{Si}=$ silt, $\mathrm{C}=$ clay and $\mathrm{L}=$ loam).

\begin{tabular}{|c|c|c|c|c|c|c|c|}
\hline \multicolumn{4}{|c|}{ Calculations from Measured Properties } & \multicolumn{4}{|c|}{ Calculations from Theoretical Soils } \\
\hline Location & $\mathbf{K}_{\mathrm{sG}}$ & $\alpha^{*}$ & $h_{c}$ & Soil Class & $\mathbf{K}_{\mathrm{sG}}$ & $\alpha^{*}$ & $h_{c}$ \\
\hline & $\left(\mathrm{cm} \mathrm{h}^{-1}\right)$ & $\left(\mathrm{cm}^{-1}\right)$ & $(-\mathbf{k P a})$ & & $\left(\mathrm{cm} \mathrm{h}^{-1}\right)$ & $\left(\mathrm{cm}^{-1}\right)$ & $(-\mathbf{k P a})$ \\
\hline loc_2 & 0.028 & 0.021 & 12.0 & SC & 0.002 & 0.0093 & 7.5 \\
\hline loc_4 4 & 0.039 & 0.0224 & 12.5 & S & 0.366 & 0.049 & 8.4 \\
\hline loc_5 & 0.393 & 0.0272 & 17.9 & $\mathrm{C}$ & 0.005 & 0.0108 & 13.5 \\
\hline loc_8 & 0.03 & 0.0232 & 10.7 & $\mathrm{SiC}$ & 0.007 & 0.0117 & 14.6 \\
\hline loc_9 & 0.025 & 0.0198 & 12.5 & LS & 0.039 & 0.0189 & 15.7 \\
\hline loc_11 & 0.278 & 0.0342 & 12.5 & SCL & 0.01 & 0.0123 & 16.7 \\
\hline loc_14 & 0.01 & 0.0161 & 10.8 & SL & 0.022 & 0.0148 & 17.9 \\
\hline loc_15 & 0.161 & 0.0293 & 13.3 & CL & 0.016 & 0.0134 & 18.3 \\
\hline loc_16 & 0.014 & 0.0194 & 10.0 & $\mathrm{~L}$ & 0.024 & 0.0133 & 21.6 \\
\hline loc_18 & 0.011 & 0.0203 & 8.0 & SiCL & 0.023 & 0.0125 & 23.2 \\
\hline loc_19 & 0.01 & 0.0165 & 10.7 & $\mathrm{Si}$ & 0.068 & 0.0134 & 29.0 \\
\hline loc_22 & 0.038 & 0.0253 & 10.4 & SiL & 0.041 & 0.0108 & 33.3 \\
\hline loc_23 & 0.026 & 0.0183 & 14.2 & & & & \\
\hline avg & 0.076 & 0.0217 & 12.1 & & & & \\
\hline sd & 0.119 & 0.0059 & -2.4 & & & & \\
\hline $\begin{array}{l}\text { Coefficient of } \\
\text { variation }(\%)\end{array}$ & 149.541 & 99.2312 & -11.8 & & & & \\
\hline $\max$ & 0.393 & 0.0342 & 8.0 & & & & \\
\hline $\min$ & 0.005 & 0.0108 & 17.9 & & & & \\
\hline
\end{tabular}

Table 4 presents the proportion of time during the growing season spent above the average $h_{c}$ value. No difference between treatments were observed even if $h_{c}$ was on average exceeded for a 
considerable (24\%) proportion of the season for all treatments. This suggests that an irrigation set point higher than $-18 \mathrm{kPa}$ would most likely have been more appropriate for strawberry production in this soil. This also suggests that even with the extent of the variation observed in soil properties at the experimental site, their effects on hydraulic behavior were random and most likely affected all treatments equally, regardless of the management scale. In this specific case, no benefits regarding the avoidance of condition limiting root water uptake could be obtained by applying a site-specific management. This also suggests that any location of the monitoring stations used for irrigation management would be as adequate as the other. As shown by the $h_{c}$ values obtained for the theoretical soils (Table 3), greater within-field differences in soil properties would probably be required to observe changes in the response to site-specific management. In this case, any effect of the management scale on crop production and water use are most likely attributed to practical effects of the management scale, for instance differences in the hardship to maintain the soil in the intended humidity range.

Table 4. Number of irrigations, average achieved irrigation threshold (IT), average soil water potential (SWP) and water use resulting from the application of the experimental treatments. Values followed by a same letter do not statistically differ according to a least significant difference (LSD) multiple comparison test. The last row presents the $p$ value from a standard ANOVA.

\begin{tabular}{ccccccc}
\hline TRT & $\begin{array}{c}\text { Number of } \\
\text { Irrigations }\end{array}$ & $\begin{array}{c}\text { Total } \\
\text { Irrigation } \\
\text { Time }\end{array}$ & avg IT & avg SWP & $\begin{array}{c}\text { Time Spent } \\
\text { Below } \boldsymbol{h}_{\boldsymbol{c}}\end{array}$ & Water Use \\
\hline & $\mathbf{( - )}$ & $\mathbf{( m i n )}$ & $\mathbf{( - \mathbf { k P a } )}$ & $\mathbf{( - \mathbf { k P a } )}$ & $\mathbf{( \% )}$ & $\mathbf{( m}^{\mathbf{3}} \mathbf{h a}^{-\mathbf{1})}$ \\
\hline Pulse & $53 \pm 9 \mathrm{a}$ & $1963 \pm 349 \mathrm{a}$ & $15.7 \pm 5.5 \mathrm{a}$ & $8.3 \pm 1.5 \mathrm{a}$ & $23.0 \pm 7.0 \mathrm{a}$ & $1427.2 \pm 304.1 \mathrm{a}$ \\
Inter & $62 \pm 17 \mathrm{a}$ & $2471 \pm 510 \mathrm{a}$ & $22.7 \pm 3.5 \mathrm{~b}$ & $10.0 \pm 1.7 \mathrm{ab}$ & $26.7 \pm 2.4 \mathrm{a}$ & $1322 \pm 218.0 \mathrm{a}$ \\
Local $_{\text {Global }}{ }^{1}$ & $56 \pm 7 \mathrm{a}$ & $2247 \pm 275 \mathrm{a}$ & $20.3 \pm 2.5 \mathrm{ab}$ & $9.3 \pm 2.1 \mathrm{a}$ & $24.2 \pm 6.9 \mathrm{a}$ & $1566.7 \pm 119.8 \mathrm{a}$ \\
$p$ & $63 \mathrm{a}$ & $2353 \mathrm{a}$ & $20.3 \pm 5.9 \mathrm{ab}$ & $12.7 \pm 1.1 \mathrm{~b}$ & $23.4 \pm 4.1 \mathrm{a}$ & $1097.2 \pm 132.12$ \\
\hline
\end{tabular}

\footnotetext{
${ }^{1}$ Since all reps were simultaneously irrigated, it is not possible to calculate a standard deviation for number of irrigations and total irrigation time. ${ }^{2}$ Global was not included in the statistical analysis on Water use, the lower water application for this treatment being attributable to problems establishing pressure in the drip laterals. ${ }^{*}$ This is standard notation for a statistically significant $p$ value.
}

\subsection{Irrigation Management and Water Use}

From planting until early June, precipitation and the weekly application of fertilizers through the drip irrigation system provided sufficient water to maintain the soil water potential above the predefined irrigation threshold of $-18 \mathrm{kPa}$. Consequently, the treatment application began in mid-June and was continued until early October. During that 104-day period, total rainfall was $324 \mathrm{~mm}$ (including $111 \mathrm{~mm}$ from two isolated rainstorms), and there were 80 days without rain. Figure 6 shows the SWP with respect to time for one replicate of each treatment in the month of September, which is the peak strawberry production period in the experimental area. It shows that all the treatments were maintained in the intended SWP range for most of the period. However, because of some practical delays to initiate irrigation (displacement time of the irrigator on the farm, valve adjustments, pump maintenance and availability), the achieved seasonal threshold (Table 4) was $2-4 \mathrm{kPa}$ lower than the intended threshold for all scale management treatments. The intended threshold was exceeded more frequently in the Global treatment (Figure 6A). It appeared that irrigation management based on the mean value of three SWP measurements caused the intended threshold to be frequently exceeded within the individual plots. Conversely, for the treatments with individually managed plots (Inter, Local, Pulse), the intended threshold was exceeded much less frequently. However, as discussed previously, the SWP was above $h_{c}$ for the same proportion of time for all treatments. Thus, these threshold exceedances should not have caused differences in plant root water uptake between the management scale treatments. However, a more precise evaluation of the effects of successions of short periods where the SWP is below $\mathrm{h}_{\mathrm{c}}$ could require more attention in further studies and would probably be easier to identify in controlled environment experiments. 


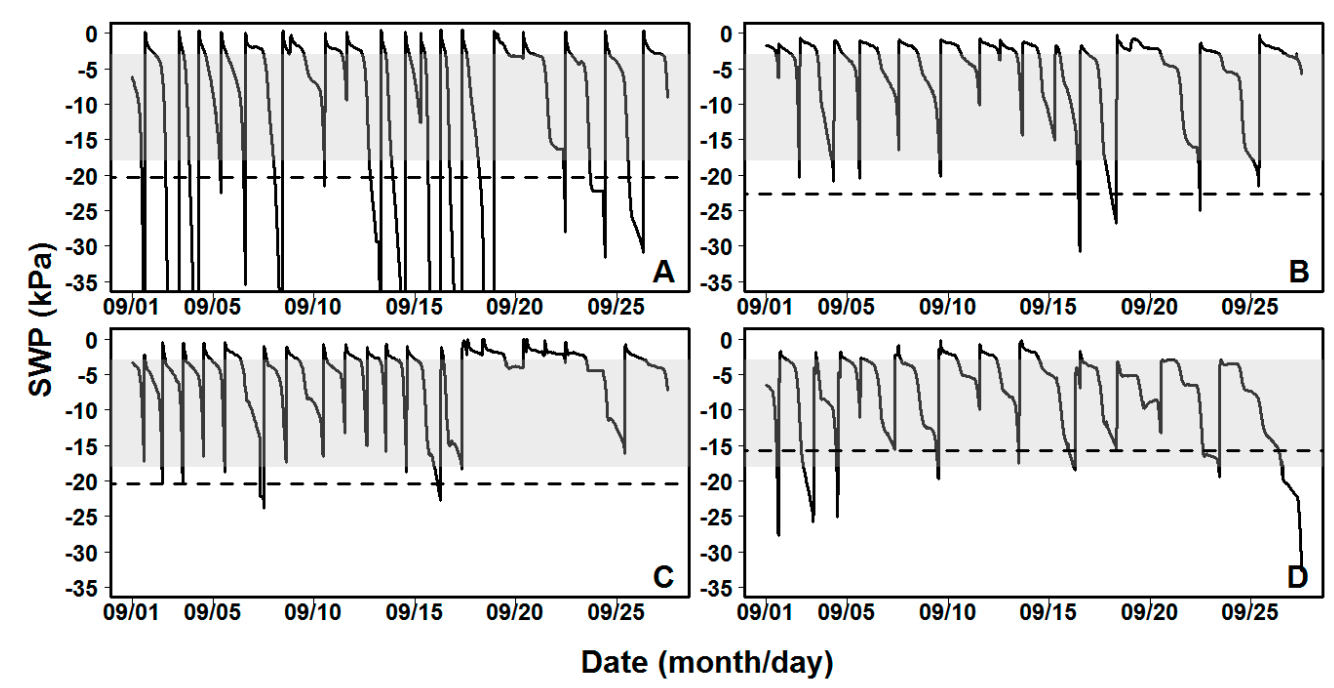

Figure 6. Soil matric potential during the month of September 2012 for one replicate of: (A) Global, (B) Inter, (C) Local and (D) Pulse treatments. The dashed lines and the grayed area represent the average achieved irrigation threshold and the intended management soil water potential range, respectively. For clarity, only one representative replicate (out of 3) is shown.

The Pulse treatment (Figure 6D) allowed a better agreement between intended and achieved thresholds. Throughout the experiment, SWP changed more gradually between -10 and $-18 \mathrm{kPa}$ for the Pulse treatment than for the other treatments, thus allowing a longer period for intervention (displacement to the field, valve adjustments, pump startup) when SWP was nearing the intended threshold, which facilitated the initiation of irrigation at the intended threshold. This slower change suggests that the Pulse treatment maintained more available water within the root zone, most likely by reducing leaching or allowing greater horizontal distribution of water within the beds. This would be consistent with the simulation results obtained in other studies [30,36]. A more specific investigation would be required to confirm it.

The number of irrigation events and the total seasonal irrigation time (Table 3) did not differ significantly among treatments. An average of 0.73 irrigation events were initiated per day without rain (for the Pulse treatment, 1 irrigation initiation event implies 2 pulses). However, the total volume of applied irrigation water was significantly lower for the Global treatment compared with the Local treatment and represented water savings of 30\%. The Inter and Pulse treatments required intermediate volumes of water, but were not statistically different from other treatments. The lower volume of water application over a similar irrigation time in the Global treatment can be partially explained by the longer delay between irrigation initiation and the achievement of the optimal emitter pressure, and hence the nominal flow rate, throughout the drip laterals. The average SWP for each treatment is also presented in Table 3. The SWP was significantly lower in the Global treatment as a result of the lower volume of water applied. The average SWP in the scale management treatments was within the optimal range for strawberry production reported in various studies $[10,16,18,19]$, so there were practical benefits to reducing the management scale as it was easier to achieve the intended threshold, and significantly higher SWP was maintained at smaller management scales (Table 3). The Pulse treatment had the added benefit of an increased intervention time to initiate irrigation when the SWP values approached the threshold.

\subsection{Yield, WP and Growth Indicators}

As indicated in Table 5, the irrigation management scale had no effect on marketable yield. Conversely, the Pulse water application method significantly improved yield by $22.4 \%$ compared to the other three treatments. This increase in yield is within the range observed by Wang et al. [63] for potatoes under high-frequency irrigation. WP showed a tendency to decrease as the management 
scale was reduced, which differs from the results of King et al. [20] and Périard et al. [14]. At the same management scale, the Pulse treatment led to a significant (36.8\%) increase in WP relative to the Local treatment, which is consistent with the results of previous studies on potatoes and bell peppers $[39,63]$. In summary, the pulsed irrigation method was shown to increase yield by $22 \%$ and water productivity by $36 \%$ relative to conventional irrigation practices. More experiments are required to understand if this improvement is due to a lower average seasonal SWP, a better distribution of water within the growth beds, or a reduction in water leaching under the root zone.

Table 5. Marketable yield, water use, fruit quality and growth indicators from the production experiment. Values followed by a same letter do not statistically differ according to a LSD multiple comparison test. The last row presents the $p$ value from a standard ANOVA. Standard statistical annotation one asterisk means significant, two mean very significant.

\begin{tabular}{|c|c|c|c|c|c|c|c|c|}
\hline TRT & $\begin{array}{l}\text { Marketable } \\
\text { Yield }\end{array}$ & WP & Dry Biomass & Fruit Size & $\begin{array}{l}\text { Brix } \\
\text { Index }\end{array}$ & Firmness & $\begin{array}{c}\text { Crown } \\
\text { DiameterGrowth } \\
\text { Rate }\end{array}$ & $\begin{array}{c}\text { Leaf } \\
\text { AreaGrowth } \\
\text { Rate }\end{array}$ \\
\hline & $\left(\mathrm{kg} \mathrm{ha}^{-1}\right)$ & $\left(\mathrm{kg} \mathrm{m}^{-3}\right)$ & (g/plant) & (g/fruit) & $(\%)$ & $\left(\mathrm{g} \mathrm{g}^{-1}\right)$ & $\left(\mathrm{mm} \mathrm{d}^{-1}\right)$ & $\left(\mathrm{cm}^{2} \mathrm{~d}^{-1}\right)$ \\
\hline Inter & $23805 \pm 3205 b$ & $18 \pm 3 a b$ & $41.6 \pm 6.6 a$ & $13.1 \pm 0.3 a$ & $9.4 \pm 0.2 \mathrm{a}$ & $222.9 \pm 5.2 \mathrm{a}$ & $0.2 \pm 0.1 \mathrm{a}$ & $85.7 \pm 15.9 \mathrm{a}$ \\
\hline Local & $23740 \pm 2065 b$ & $15 \pm 2 b$ & $35.0 \pm 4.7 \mathrm{a}$ & $13.5 \pm 0.4 a$ & $8.9 \pm 0.1 \mathrm{a}$ & $243.1 \pm 19.0 \mathrm{a}$ & $0.2 \pm 0.1 \mathrm{a}$ & $75.4 \pm 21.9 a$ \\
\hline Global & $23444 \pm 2725 b$ & $21 \pm 4^{1}$ & $36.8 \pm 11.4 \mathrm{a}$ & $13.0 \pm 0.2 a$ & $9.5 \pm 0.1 \mathrm{a}$ & $225.2 \pm 0.5 \mathrm{a}$ & $0.2 \pm 0.1 \mathrm{a}$ & $74.7 \pm 27.5 \mathrm{a}$ \\
\hline
\end{tabular}

${ }^{1}$ Global was not included in the statistical analysis on WP, the lower water application for this treatment being attributable to problems establishing pressure in the drip laterals.

In contrast with studies reporting an influence of water application on fruit size [17,19], no difference was observed among any of the treatments in this experiment. As noted by Giné Bordonaba and Terry [64], this result can be attributed to varietal specificities. In their study, the fruit size of two out of five cultivars was not influenced by the irrigation management. The increase in yield associated with the Pulse treatment is thus attributable to a greater number of fruits. No significant differences in fruit quality (soluble sugar content or firmness) were observed among any of the treatments, but the fruits from the Local treatments showed a nearly significant tendency $(p=0.054)$ for a lower brix index. These results are consistent with observations by Giné Bordonaba and Terry (2010) [64], who found an increase in fruit sugar content in response to deficit irrigation, but they differ with the findings of Hoppula and Salo [18], who reported an increase in firmness and sugar content with a higher SWP for one out of three harvest periods.

The leaf coverage and crown diameter growth rates were similar among all treatments. This is consistent with other studies in which no effect of irrigation management on vegetative plant growth was observed [18,65]. The effect of irrigation on these parameters is also likely to be specific to the cultivar under study and is difficult to evaluate under field conditions because of the random effects of rain, wind, and damage from agricultural operations. In studies conducted under tunnels or greenhouses, leaf area and leaf architecture were reported to be affected by irrigation $[66,67]$.

\section{Conclusions}

This study demonstrated that in a field where soil properties exhibited a great level of randomly distributed variability, intensive soil sampling and geostatistical analysis could not delineate irrigation management zones. High-definition sensing methods like electrical conductivity mapping with mobile instruments and water content mapping from spectral imagery might be more adequate for this purpose. Even if calculated critical irrigation thresholds did not present a structured spatial variability, they provided realistic estimates when based on the measured hydraulic properties and could be used as irrigation management guidelines. However, when calculated based on soil texture and pedotransfer functions, critical irrigation thresholds were unrealistic for strawberry production. More work is required to derive hydraulic properties from simple properties or from high-density remote sensing data. 
Contrary to previous reports with other crops, the irrigation management scale had no influence on yield, and there was a trend for a decrease in water productivity with a reduction in management scale. However, pulsed irrigation water application based on SWP increased yield and WP considerably without affecting fruit quality. This suggests that further studies aiming to improve yield and WP in field strawberry production in similar conditions should focus on water application methods and not on the size of irrigation management units. More field- and/or simulation-based experiments designed to evaluate the impacts of different combinations of irrigation thresholds and water application methods are still needed to optimize irrigation practices in similar soil conditions.

Author Contributions: Conceptualization, writing-review and editing, G.L. and J.C. methodology, validation, formal analysis, investigation, writing-original draft preparation, G.L. supervision, project administration, resources, funding acquisition, J.C.

Funding: This research was funded by the Natural Sciences and Engineering Research Council of Canada (NSERC), Hortau, and Ferme Onésime Pouliot.

Acknowledgments: The authors would like to express their gratitude to Ferme Onésime Pouliot for providing the experimental site as well as for their technical and financial contributions to the research project. We also thank Jacques Gallichand and Claire Depardieu for their helpful comments.

Conflicts of Interest: No conflict of interests to report.

\section{Appendix A}
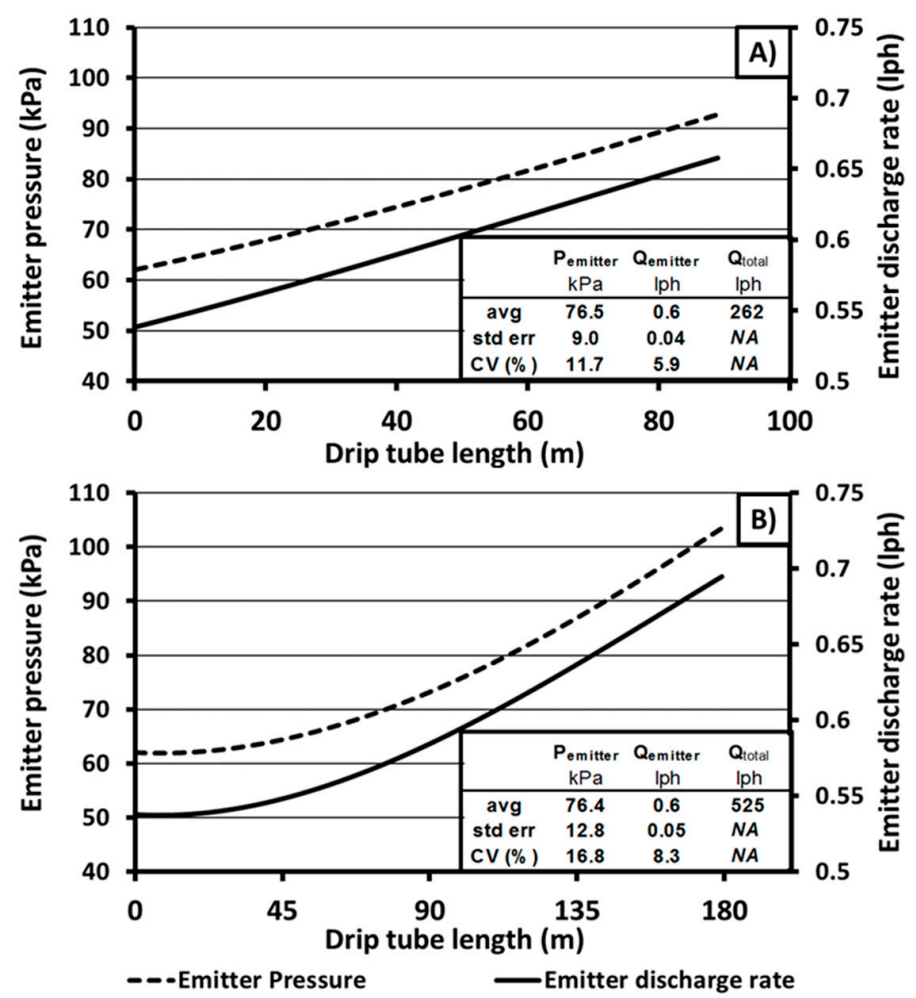

Figure A1. Emitter pressure and discharge rate as a function of drip tube length for (A) the $90 \mathrm{~m}$-long plots (Local, Pulse) and (B) the $180 \mathrm{~m}$-long zones (Inter, Global).

Pressure in the drip tubes were calculated with:

$$
\begin{gathered}
h l_{0-i}=h l_{0-L}-h l_{i-L} \\
P_{i}=P_{0}-\left(h l_{0-i}+k d z_{0-i}\right)
\end{gathered}
$$

where: 
- $\quad P_{0}=$ Inlet pressure head $(\mathrm{kPa})$

- $P_{i}=$ Pressure head at the $i$ th emitter $(\mathrm{kPa})$

- $k=$ Constant for unit conversion $\left(9.81 \mathrm{kPa} \mathrm{m}^{-1}\right)$

- $\quad h l=$ Friction pressure losses calculated with the Hanzen-Williams equation (m)

- $d z=$ Elevation difference $(\mathrm{m})$

Discharge rate of the emitters was calculated with:

$$
Q_{\mathrm{i}}=k P_{\mathrm{i}}^{x}
$$

where:

- $Q_{\mathrm{i}}=$ Discharge rate at the $i$ th emitter $\left(\mathrm{h}^{-1}\right)$

- $k=$ Unit conversion constant

- $x=$ Manufacturer supplied emitter exponent (0.5)

\section{References}

1. Assouline, S.; Möller, M.; Furman, A.; Narkis, K.; Silber, A. Impact of Water Regime and Growing Conditions on Soil-Plant Interactions: From Single Plant to Field Scale. Vadose Zo. J. 2012, 11. [CrossRef]

2. OECD (Organisation for Economic Co-operation and Development). Sustainable Management of Water Resources in Agriculture; OECD Publishing: Paris, Italy, 2010; ISBN 9789264083455.

3. Morillo, J.G.; Martín, M.; Camacho, E.; Díaz, J.A.R.; Montesinos, P. Toward precision irrigation for intensive strawberry cultivation. Agric. Water Manag. 2014, 151, 43-51. [CrossRef]

4. Hanson, B.R.; Bendixon, W. Drip irrigation evaluated in Santa Maria Valley strawberries. Calif. Agric. 2004, 58, 48-53. [CrossRef]

5. Gumiere, S.J.; Lafond, J.A.; Hallema, D.W.; Yann, P.; Caron, J.; Gallichand, J. Irrigated Agriculture Mapping soil hydraulic conductivity and matric potential for water management of cranberry: Characterisation and spatial interpolation methods. Biosyst. Eng. 2014, 128, 29-40.

6. Muralidharan, D.; Knapp, K.C. Spatial dynamics of water management in irrigated agriculture. Water Resour. Res. 2009, 45, W05411. [CrossRef]

7. Russo, D. A geostatistical approach to the trickle irrigation design in heterogeneous soil: 1 . Theory. Water Resour. Res. 1983, 19, 632-642. [CrossRef]

8. Sadler, E.J.; Evans, R.G.; Buchleiter, G.W.; King, B.A.; Camp, C.R. Design considerations for site specific irrigation. In Proceedings of the 4th Decennial Symposium, Phoenix, AZ, USA, 14-16 November 2000; pp. 304-315.

9. Kandelous, M.M.; Kamai, T.; Vrugt, J.A.; Šimůnek, J.; Hanson, B.; Hopmans, J.W. Evaluation of subsurface drip irrigation design and management parameters for alfalfa. Agric. Water Manag. 2012, 109, 81-93. [CrossRef]

10. Létourneau, G.; Caron, J.; Anderson, L.; Cormier, J. Matric potential-based irrigation management of field-grown strawberry: Effects on yield and water productivity. Agric. Water Manag. 2015, 161, 102-113. [CrossRef]

11. Shock, C.C.; Wang, F.X. Soil water tension, a powerful measurement for productivity and stewardship. HortScience 2011, 46, 178-185. [CrossRef]

12. Pelletier, V.; Gallichand, J.; Caron, J. Effect of Soil Water Potential Threshold for Irrigation on Cranberry Yield and Water Productivity. Trans. Am. Soc. Agric. Biol. Eng. 2013, 56, 1325-1332.

13. Pelletier, V.; Gallichand, J.; Caron, J.; Jutras, S.; Marchand, S. Critical irrigation threshold and cranberry yield components. Agric. Water Manag. 2015, 148, 106-112. [CrossRef]

14. Périard, Y.; Caron, J.; Jutras, S.; Lafond, J.A.; Houlliot, A. Irrigation management of romaine lettuce in histosols at two spatial scales: Water, energy, leaching and yield impacts. WIT Trans. Ecol. Environ. 2012, 168, $171-188$.

15. Rekika, D.; Caron, J.; Rancourt, G.T.; Lafond, J.A.; Gumiere, S.J.; Jenni, S.; Gosselin, A. Optimal Irrigation for Onion and Celery Production and Spinach Seed Germination in Histosols. Agron. J. 2014, 106, 981-994. [CrossRef] 
16. Bergeron, D. Régie de l'irrigation goutte à goutte dans la production de fraises à jour neutres au Québec. Master's Thesis, Laval University, Québec, QC, Canada, 2010.

17. Guimerà, J.; Marfà, O.; Candela, L.; Serrano, L. Nitrate leaching and strawberry production under drip irrigation management. Agric. Ecosyst. Environ. 1995, 56, 121-135. [CrossRef]

18. Hoppula, K.; Salo, T. Tensiometer-based irrigation scheduling in perennial strawberry cultivation. Irrig. Sci. 2007, 25, 401-409. [CrossRef]

19. Peñuelas, J.; Savé, R.; Marfà, O.; Serrano, L. Remotely measured canopy temperature of greenhouse strawberries as indicator of water status and yield under mild and very mild water stress conditions. Agric. For. Meteorol. 1992, 58, 63-77. [CrossRef]

20. King, B.A.; Stark, J.C.; Wall, R.W. Comparison of Site-Specific and Conventional Uniform Irrigation Management for Potatoes. Appl. Eng. Agric. 2006, 22, 677-688. [CrossRef]

21. El Nahry, A.H.; Ali, R.R.; Baroudy, A.A. El An approach for precision farming under pivot irrigation system using remote sensing and GIS techniques. Agric. Water Manag. 2011, 98, 517-531. [CrossRef]

22. Hedley, C.B.; Yule, I.J.; Tuohy, M.P.; Vogeler, I. Key performance indicators for simulated variable-rate irrigation of variable soils in humid regions. Trans. ASABE 2009, 52, 1575-1584. [CrossRef]

23. Jobbágy, J.; Simoník, J.; Findura, P. Evalutaion of efficiency of precision irrigation for potatoes. Res. Agr. Eng. 2011, 57, S14-S23. Available online: http://www.agriculturejournals.cz/publicFiles/52458.pdf (accessed on 15 Jan 2015).

24. Feinerman, E. Site-specific management of agricultural inputs: An illustration for variable-rate irrigation. Eur. Rev. Agric. Econ. 2000, 27, 17-37. [CrossRef]

25. Evans, R.G.; King, B.A.; Food, T. Site-Specific Sprinkler Irrigation in a Water-Limited Future. Trans. ASABE 2012, 55, 493-504. [CrossRef]

26. Communar, G.; Friedman, S.P. Relative Water Uptake Rate as a Criterion for Trickle Irrigation System Design: I. Coupled Source-Sink Steady Water Flow Model. Soil Sci. Soc. Am. J. 2010, 74, 1493. [CrossRef]

27. Cook, F.J.; Fitch, P.; Thorburn, P.J.; Charlesworth, P.B.; Bristow, K.L. Modelling trickle irrigation: Comparison of analytical and numerical models for estimation of wetting front position with time. Environ. Model. Softw. 2006, 21, 1353-1359. [CrossRef]

28. Naglic, B.; Kechavarzi, C.; Pintar, M. Modelling of Water Distribution Under Drip Irrigation Systems. Hop Bull. 2012, 19, 100-114.

29. Russo, D.; Laufer, A.; Silber, A.; Assouline, S. Water uptake, active root volume, and solute leaching under drip irrigation: A numerical study. Water Resour. Res. 2009, 45, W12413. [CrossRef]

30. Skaggs, T.H.; Trout, T.J.; Rothfuss, Y. Drip Irrigation Water Distribution Patterns: Effects of Emitter Rate, Pulsing, and Antecedent Water. Soil Sci. Soc. Am. J. 2010, 74, 1886. [CrossRef]

31. Subbaiah, R. A review of models for predicting soil water dynamics during trickle irrigation. Irrig. Sci. 2011, 31, 225-258. [CrossRef]

32. Kandelous, M.M.; Šimůnek, J. Numerical simulations of water movement in a subsurface drip irrigation system under field and laboratory conditions using HYDRUS-2D. Agric. Water Manag. 2010, 97, 1070-1076. [CrossRef]

33. Yuan, F.; Lu, Z. Analytical Solutions for Vertical Flow in Unsaturated, Rooted Soils with Variable Surface Fluxes. Vadose Zo. J. 2005, 4, 1210. [CrossRef]

34. Anderson, L. Détermination de la stratégie d'irrigation optimale de la fraise basée sur le potentiel matriciel du sol et un modèle climatique. Master's Thesis, Laval University, Québec, QC, Canada, 2015.

35. Friedman, S.P.; Communar, G.; Gamliel, A. DIDAS-User-friendly software package for assisting drip irrigation design and scheduling. Comput. Electron. Agric. 2016, 120, 36-52. [CrossRef]

36. Cote, C.M.; Bristow, K.L.; Charlesworth, P.B.; Cook, F.J.; Thorburn, P.J. Analysis of soil wetting and solute transport in subsurface trickle irrigation. Irrig. Sci. 2003, 22, 143-156. [CrossRef]

37. Camposeo, S.; Rubino, P. Effect of irrigation frequency on root water uptake in sugar beet. Plant Soil 2003, 253, 301-309. [CrossRef]

38. Segal, E.; Ben-Gal, A.; Shani, U. Root Water Uptake Efficiency Under Ultra-High Irrigation Frequency. Plant Soil 2006, 282, 333-341. [CrossRef]

39. Dukes, M.D.; Davis, W.E.; Simonne, E.H.; Studstill, D.W.; Hochmuth, R. Effects of sensor-based high frequency irrigation on bell pepper yield and water use. In Proceedings of the 2nd International Conference on Irrigation and Drainage, Phoenix, AZ, USA, 12-15 May 2003; pp. 665-674. 
40. Soil Classification Working Group. The Canadian System of Soil Classification, 3rd ed.; Agriculture and Agri-Food Canada Publication 1646, National Research Council: Ottawa, ON, Canada, 1998.

41. Williams, G.S.; Hazen, A. Hydraulic Tables: The Elements of Gagings and the Friction of Water Flowing in Pipes, Aqueducts, Sewers, Etc. as Determined by the Hazen and Williams Formula and the Flow of Water Over Sharp-edged and Irregular Weirs, and the Quantity Discharged, as Determined by Bazin's Formula and Experimental Investigations Upon Large Models, 2nd ed.; J. Wiley \& Sons: Hoboken, NJ, USA, 1914.

42. Gee, G.W.; Or, D. 2.4.3.5 Hydrometer Method. In Methods of Soil Analysis, Part 4. Physical Methods; Soil Science Society of America Inc.: Madison, WI, USA, 2002; pp. 278-283.

43. Reynolds, W.D.; Elrick, D.E.; Young, E.G. 3.4.2.2 Constant Head Soil Core (tank) Method. In Methods of Soil Analysis. Part 4-Physical Methods; Dane, J.H., Topp, C.G., Eds.; Soil Science Society of America, Inc.: Madison, WI, USA, 2002; pp. 804-809.

44. Romano, N.; Hopmans, J.W.; Dane, J.H. 3.3.2.6 Suction Table. In Methods of Soil Analysis, Part 4. Physical Methods; Dane, J.H., Topp, G.C., Eds.; Soil Science Society of America, Inc.: Madison, WI, USA, 2002; Volume 5, pp. 692-698.

45. Hopmans, J.W.; Šimůnek, J.; Romano, N.; Durner, W. Multistep Outflow Method. In Method of soil analysis, Part 4. Physical Methods; Dane, J.H., Topp, C.G., Eds.; Soil Science Society of America, Inc.: Madison, WI, USA, 2002; pp. 971-978.

46. Banton, O.; Côté, D.; Trudelle, M. Détermination au champ de la conductivité hydraulique saturée à l'aide de l'infiltromètre à charge constante de côté: Théorie et approximations théoriques. Can. J. Soil Sci. 1991, 71, 119-126. [CrossRef]

47. Grossman, R.B.; Reinsch, T.J. 2.1.1.4 Dealing with Rock Fragments. In Methods of Soil Analysis, Part 4. Physical Methods; Dane, J.H., Topp, C.G., Eds.; Soil Science Society of America, Inc.: Madison, WI, USA, 2002; pp. 205-207.

48. Elzhov, T.V.; Mullen, K.M.; Spiess, A.-N.; Bolker, B. minpack.lm: R Interface to the Levenberg-Marquardt Nonlinear Least-Squares Algorithm Found in MINPACK, Plus Support for Bounds 2016, version 1.2-1, p. 14. Available online: https://cran.r-project.org/web/packages/minpack.lm/minpack.lm.pdf (accessed on 31 May 2019).

49. Schaap, M.G.; Leij, F.J.; Van Genuchten, M.T. Rosetta: A computer program for estimating soil hydraulic parameters with hierarchical pedotransfer functions. J. Hydrol. 2001, 251, 163-176. [CrossRef]

50. Pinheiro, J.; Bates, D.; DebRoy, S.; Sarkar, D.; Team, T.R.C. nlme: Linear and Nonlinear Mixed Effects Models. $R$ Packag. 2013, 3, 111.

51. R Core Team. R: A Language and Environment for Statistical Computing; R Foundation for Statistical Computing: Vienna, Austria, 2014.

52. Webster, R.; Oliver, M.A. Geostatistics for Environmental Scientists, 2nd ed.; John Wiley and Sons: Hoboken, NJ, USA, 2007.

53. Ribeiro, P.J.; Diggle, P.J. geoR: A package for geostatistical analysis. R-News 2001, 1, 14-18.

54. Poesen, J.; Lavee, H. Rock fragments in top soils: significance and processes. CATENA 1994, 23, 1-28. [CrossRef]

55. Milne, A.E.; Lark, R.M.; Addiscott, T.M.; Goulding, K.W.T.; Webster, C.P.; O'Flaherty, S. Wavelet analysis of the scale- and location-dependent correlation of modelled and measured nitrous oxide emissions from soil. Eur. J. Soil Sci. 2005, 56, 3-17. [CrossRef]

56. Cousin, I.; Nicoullaud, B.; Coutadeur, C. Influence of rock fragments on the water retention and water percolation in a calcareous soil. CATENA 2003, 53, 97-114. [CrossRef]

57. Tetegan, M.; Richer de Forges, A.C.; Verbeque, B.; Nicoullaud, B.; Desbourdes, C.; Bouthier, A.; Arrouays, D.; Cousin, I. The effect of soil stoniness on the estimation of water retention properties of soils: A case study from central France. CATENA 2015, 129, 95-102. [CrossRef]

58. Strudley, M.; Green, T.; Ascoughii, J. Tillage effects on soil hydraulic properties in space and time: State of the science. Soil Tillage Res. 2008, 99, 4-48. [CrossRef]

59. Alletto, L.; Coquet, Y. Temporal and spatial variability of soil bulk density and near-saturated hydraulic conductivity under two contrasted tillage management systems. Geoderma 2009, 152, 85-94. [CrossRef]

60. Li, T.; Hao, X.; Kang, S. Spatiotemporal Variability of Soil Moisture as Affected by Soil Properties during Irrigation Cycles. Soil Sci. Soc. Am. J. 2014, 78, 598. [CrossRef] 
61. Torri, D.; Poesen, J.; Monaci, F.; Busoni, E. Rock fragment content and fine soil bulk density. CATENA 1994, 23, 65-71. [CrossRef]

62. Bechini, L.; Bocchi, S.; Maggiore, T. Spatial interpolation of soil physical properties for irrigation planning. A simulation study in northern Italy. Eur. J. Agron. 2003, 19, 1-14. [CrossRef]

63. Wang, F.-X.; Kang, Y.; Liu, S.-P. Effects of drip irrigation frequency on soil wetting pattern and potato growth in North China Plain. Agric. Water Manag. 2006, 79, 248-264. [CrossRef]

64. Giné Bordonaba, J.; Terry, L.A. Manipulating the taste-related composition of strawberry fruits (Fragaria $\times$ ananassa) from different cultivars using deficit irrigation. Food Chem. 2010, 122, 1020-1026. [CrossRef]

65. Pires, R.C.D.M.; Folegatti, M.V.; Passos, F.A.; Arruda, F.B.; Sakai, E. Vegetative growth and yield of strawberry under irrigation and soil mulches for different cultivation environments. Sci. Agric. 2006, 63, 417-425. [CrossRef]

66. Keutgen, A.J.; Pawelzik, E. Impacts of $\mathrm{NaCl}$ stress on plant growth and mineral nutrient assimilation in two cultivars of strawberry. Environ. Exp. Bot. 2009, 65, 170-176. [CrossRef]

67. Savé, R.; Penuelas, J.; Marfa, O.; Serrano, L. Changes in Leaf Osmotic and Elastic Properties and Canopy Structure of Strawberry under mild water stress. Hortscience 1993, 28, 925-927. [CrossRef]

(C) 2019 by the authors. Licensee MDPI, Basel, Switzerland. This article is an open access article distributed under the terms and conditions of the Creative Commons Attribution (CC BY) license (http://creativecommons.org/licenses/by/4.0/). 